\title{
Identifying Pathfinder Elements for Gold in Multi-Element Soil Geochemical Data from the Wa-Lawra Belt, Northwest Ghana: A Multivariate Statistical Approach
}

\author{
Prosper Mackenzie Nude ${ }^{1}$, John Mahfouz Asigri ${ }^{1}$, Sandow Mark Yidana ${ }^{1}$, \\ Emmanuel Arhin ${ }^{2}$, Gordon Foli ${ }^{3}$, Jacob Mawuko Kutu ${ }^{1}$ \\ ${ }^{1}$ Department of Earth Science, University of Ghana, Legon, Ghana \\ ${ }^{2}$ Geology Department, University of Leicester, Leicester, UK \\ ${ }^{3}$ Department of Geological Engineering, Kwame Nkrumah University of Science and Technology, Kumasi, Ghana \\ Email: "pmnude@ug.edu.gh
}

Received November 29, 2011; revised December 17, 2011; accepted January 19, 2012

\begin{abstract}
A multivariate statistical analysis was performed on multi-element soil geochemical data from the Koda Hill-Bulenga gold prospects in the Wa-Lawra gold belt, northwest Ghana. The objectives of the study were to define gold relationships with other trace elements to determine possible pathfinder elements for gold from the soil geochemical data. The study focused on seven elements, namely, $\mathrm{Au}, \mathrm{Fe}, \mathrm{Pb}, \mathrm{Mn}, \mathrm{Ag}$, As and $\mathrm{Cu}$. Factor analysis and hierarchical cluster analysis were performed on the analyzed samples. Factor analysis explained $79.093 \%$ of the total variance of the data through three factors. This had the gold factor being factor 3, having associations of copper, iron, lead and manganese and accounting for $20.903 \%$ of the total variance. From hierarchical clustering, gold was also observed to be clustering with lead, copper, arsenic and silver. There was further indication that, gold concentrations were lower than that of its associations. It can be inferred from the results that, the occurrence of gold and its associated elements can be linked to both primary dispersion from underlying rocks and secondary processes such as lateritization. This data shows that $\mathrm{Fe}$ and $\mathrm{Mn}$ strongly associated with gold, and alongside $\mathrm{Pb}, \mathrm{Ag}$, $\mathrm{As}$ and $\mathrm{Cu}$, these elements can be used as pathfinders for gold in the area, with ferruginous zones as targets.
\end{abstract}

Keywords: Multivariate Analyses; Multi-Elements; Soil Geochemical Data; Pathfinder Elements; Gold; Northwest Ghana

\section{Introduction}

The Wa-Lawra greenstone belt marks the eastern margin of the larger Proterozoic Birimian greenstone belt which trends through southern and central Burkina Faso to northern Ghana. The Birimian greenstone belt is known to host a number of significant gold (Au) and base metal deposits including the famous AngloGold-Ashanti mine in Ghana. Although the Wa-Lawra belt shares similar lithological and structural characteristics to the greenstone belts located in southwestern Ghana, which host a number of "World Class" gold deposits, discovery of substantial gold deposits from the Wa-Lawra belt in Ghana has been elusive, with Azumah Resources and Castle Minerals being the only operating exploration companies in the area. The lack of success in the discovery of potential gold deposits of commercial quantity has been partly attributed to the complex regolith structure in the area [1]. For effective interpretation of soil geochemical data and lo-

"Corresponding author. cation of economic gold, better knowledge of metal pathways in the regolith are needed. McQueen and Munro [2] have shown that the geochemical dispersion of gold and their pathfinder elements are strongly dependent on the preservation of trace elements in the regolith. So the identification of relationship among trace elements with specific minerals and mineralogical control structures such as cutans and concretions in the regolith may be a better tool to use to identify and rank gold anomalies [3]. Thus despite the problems of regolith complexities, the establishment of pathfinder elements can aid in the identification of element-host mineral associations which may provide a consistent sampling medium, reduce geochemical noise and fine-tune exploration techniques for success.

In this research, multivariate statistical methods were used for the evaluation of multi-element soil geochemical data from the Koda Hill-Bulenga gold prospects in the Wa-Lawra gold belt. These statistical methods, which are the first of its kind performed on these data, facilitated an understanding of the variations in $\mathrm{Au}$ and the relationship 
between Au concentrations and the concentrations of other elements in the soil samples. The method appears useful in the determination of possible pathfinder elements which can guide exploration activities.

\section{Location and Geology of Study Area}

The study area falls within the Birimian gold bearing belts of northern Ghana [4,5]. Figure 1 is a regional geological map of northern Ghana showing the lithological distributions. Insert is the Koda Hill-Bulenga areas located at the southeastern end of the Wa-Lawra belt where this study was done. The geology of the Wa-Lawra belt has been described by several workers including Leube et al. [6], Taylor et al. [7], Hirdes et al. [8], whiles the details of the geology of the Koda Hill-Bulenga area can be found in Nude and Arhin [9]. The area is underlain by metavolcanic, pyroclastic and metasedimentary rocks. The metavolcanic rocks are of basaltic and gabbroic in compositions and most of them have been altered into various schist. The metasedimentary rocks consist of phyllites, tuffaceous and carbonaceous phyllites, sandstones, siltstones, tuff, cherts and manganeferous sediments. Intruding the metavolcanic and metasedimentary rocks are magmatic bodies and porphyritic granitoids that have generally been classified into two broad categories. These are 1) hornblende-rich varieties that are closely associated with the volcanic rocks and known locally as "Dixcove" or "belt" type and 2) mica-rich varieties which tend to border the volcanic belt or greenstones and are found in the metasediment units, and referred to as "Cape Coast" or "basin" type granitoids. The Birimian units of the area feature most of the same lithologies observed in the greenstone belts found in southern Ghana. On a regional scale the Wa-Lawra belt can be traced northwards for several hundred kilometers into northwestern Burkina Faso where the belt is known to host several major gold and base metal deposits.

\section{Physiography and Regolith}

The landscape of northern Ghana is gently undulating at the moderate elevated areas or low pediment areas. The upland areas are generally marked by scree that decreases in fragment size down-slope. Thin layers of colluvium, which is interspersed with alluvial plains, cover the lowlying areas. In northern Ghana, most areas retain relicts of lateritic weathering profiles. The upper surficial profiles generally have a thin veneer of pisoliths and sheetwash deposit cover in the low lying areas. The area is the continuation of the extensive wooded savannah of central

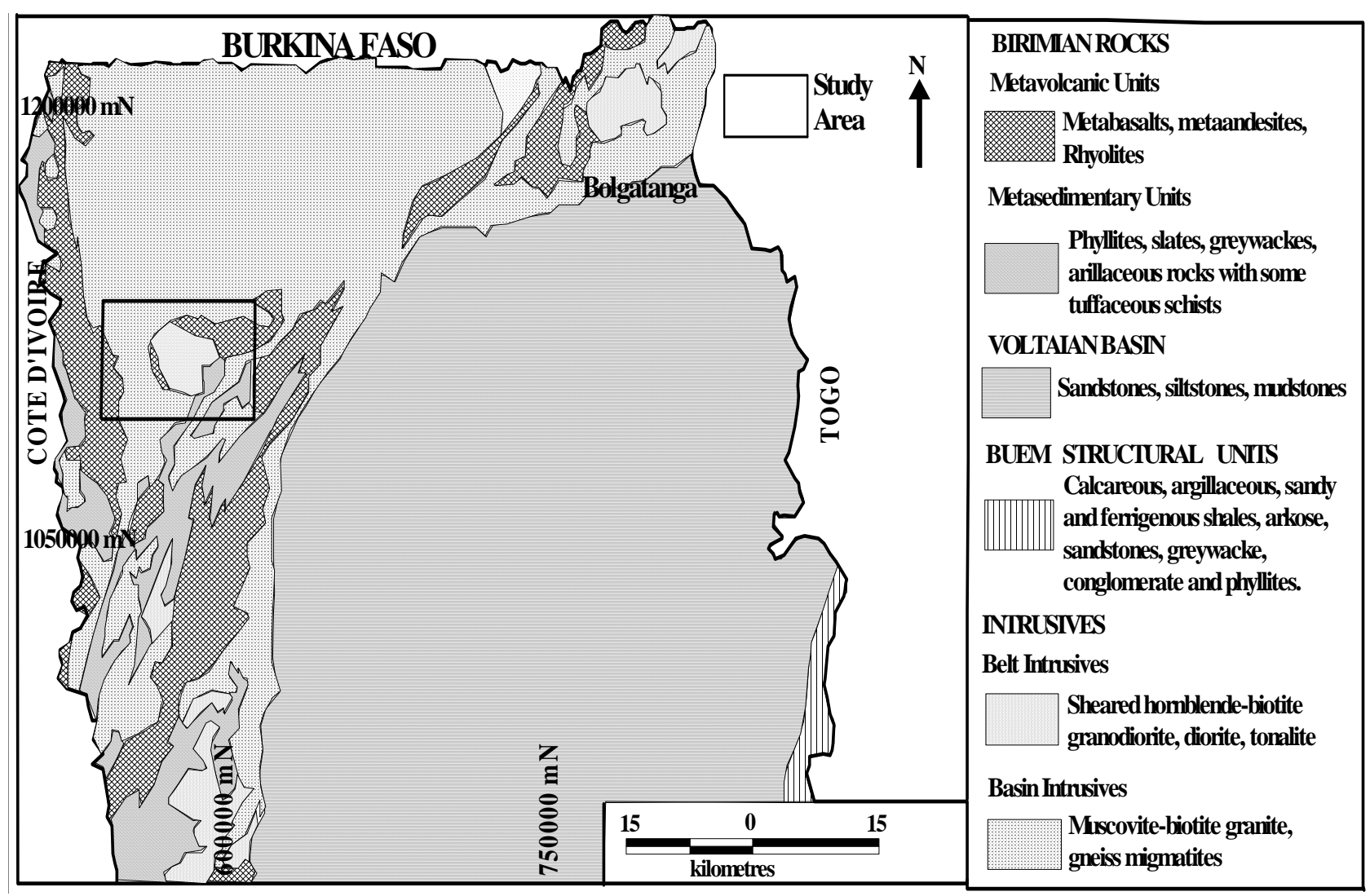

Figure 1. Geological map of northern Ghana showing the lithological distributions. Insert is the Koda Hill-Bulenga area where the study was done. 
Ghana with the annual rainfall typically in the range 1000 $1250 \mathrm{~mm} / \mathrm{yr}$ [10].

The spatial distributions of the regolith materials in the Koda Hill-Bulenga areas [1] consist of residual and transported regolith. The residual regolith materials are commonly preserved at ridge tops and high pediments, while proximal transported materials or colluviums are found at the base of ridges and often at moderate elevated terrains and are preserved on the landscapes generally as colluvial soils, screes/talus. The transported regoliths are found generally at low pediments and low lying areas and in drainage catchment areas. There are also widespread residual laterites or duricrust and ferricretes or transported laterites.

\section{History of Gold Exploration}

The occurrence of gold in Northern Ghana has been reported since 1935 [11]. Prior to this however, galamsey (small scale artisanal gold mining) activities in the area were quite prevalent. Pilot systematic conventional gold exploration started in this area in 1960 after a collaborative geological mapping and prospecting by Ghana Geological Survey and their Soviet counterpart identified and confirmed the gold occurrence reported by Junner. In 1990 BHP-Minerals undertook a regional stream sediment survey using the BLEG technique in order to cover the entire area of the Wa-Lawra belt. The stream and soil samples collected did produce some anomalies, but in comparison to southern and western Ghana, they were not considered economically viable. There also existed the likelihood that, the anomalies were entirely not even related to mineralization. Carter [12] reported that between the years of 1997 and 2000, an extensive geochemical survey was carried out encompassing the entire Wa-Lawra belt. During this period, Ashanti-AGEM Limited held prospecting rights over the entire Wa-Lawra belt. The company carried out a wide spaced reconnaissance survey involving soils, termite mounds, laterite, stream sediment and lithological grab sampling alongside geological mapping and Landsat-TM imagery studies [13]. Over 4500 soil samples were collected and analyzed. The AGEM survey defined several anomalous sub-areas, each incurporating a number of anomalous trends and clusters, mostly soil, but often supported by other sample data. Followup work on the anomalous sub-areas resulted in the definition of four contiguous priority areas that include Babile, Boiri, and Chereponi South and North. Later in 1999, AGEM farmed out the areas to the south to SEMAFO Ghana Limited. Rather interestingly, no commercial mine has been operational in the area until in 2006 when Azumah Resources commenced a new geochemical sampling program and exploration re-assessment. The company has since delineated many prospective geochemical targets with mineable resources. The Koda Hill-Bulenga areas are currently being explored by Castle Minerals Limited.

\section{Gold Mineralization}

Quartz veins occur in almost all the lithologic units of the area. However, gold-bearing quartz veins are observed in association with shear and fault zones along the contact zones of the boundaries of the metavolcanic and metasedimentary rocks, and also in the chemical sediments. The chemical sediments are of particular interest as a source of gold. According to Melcher and Stumpfl [14], the widespread manganiferous phyllites of the chemical sediments carry high background gold contents as are the gondites in the greenstone succession. The gold quartz veins reveal a secondary mineral assemblage characteristic of hydrothermal alteration i.e., chlorite, carbonate, muscovite, graphite, epidote, and sulphides.

\section{The Application of Multivariate Statistical Methods to Geochemical Data}

The multivariate and regionalized character of geochemical variables makes them an interesting candidate for numerical analysis using both geostatistics $[15,16]$ and data analysis methods [17] in order to identify geochemical anomalies. The development of low-cost, rapid multi-element analytical techniques has generated large geochemical databases in many exploration programs. When a sampling program consists of several thousand samples, the resulting data matrix is enormous and effective interpretation using all of the elements individually becomes burdensome. However, the application of multivariate statistical techniques can extract geochemical patterns related to the underlying geology, weathering, alteration and mineralization which enhance the interpretation of these patterns.

Statistical methods have been widely applied to interpret geochemical data sets and define anomalies. These methods need to be used cautiously because of the particular characteristics of geochemical data. Geochemical data sets seldom represent a single population or distribution; the data are typically spatially dependent and at each sample site, a range of different processes have influenced the element abundances measured. The data are also imprecise due to unavoidable variability in sampling methods and media and the level of analytical precision. As a result no single universally applicable statistical test has been developed for identifying anomalies. Statistical investigation should use a range of techniques to explore the nature of geochemical data before selecting anomalous values e.g. [18].

Factor analysis (FA) and Hierarchical Cluster Analysis (HCA) were applied to a multivariate geochemical dataset in this study. Factor analysis is an appropriate method for establishing element associations. When this technique is applied to a geochemical data set, it is possible to obtain several factors, as linear functions of the original chemical elements. Some of these factors can be used for 
studying a specific group of variables, giving conclusions about an association of elements, which is geochemically more significant than the study of individual variables. These techniques use the probabilistic and spatial behavior of geochemical variables, giving a tool for identifying potential anomalous areas to locate mineralization. The use of multivariate analysis also permits the study of the spatial structure intrinsic to geochemical data and the identification and refinement of significant anomalies related to Au-bearing mineral deposits. Factor analysis can simplify a complex data set by identifying one or more underlying "factors" or processes that might explain the dimensions associated with data variability [19]. The "loading” of each factor, i.e. the degree of association between each variable and each factor, allows the recognition of clusters.

Hierarchical Cluster Analysis (HCA), as the most common cluster analysis method applied for geological/hydrological analysis, looks for groups of samples according to their similarities. HCA is a powerful tool for analyzing data sets for expected or unexpected clusters including the presence of outliers. In HCA, each point forms, initially, one cluster, and the preliminary matrix is analyzed. The most similar points are grouped forming one cluster and the process is repeated until all points belong to one cluster [17]. HCA examines distances between samples and datasets. The result obtained could be presented in a two-dimensional plot called dendogram which illustrates the fusions or divisions made at each successive stage of analysis.

\section{Methodology}

For the purpose of this project, historical data from multielement soil geochemical survey conducted in the area were used. The data included over 2000 sample sites (data can be obtained from author on request) which were reduced to 249 samples after data cleaning. The soil samples were taken at depths of between $40-60 \mathrm{~cm}$ with their respective coordinates taken and recorded. Other parameters which were recorded during sampling were the landscape, regolith and vegetation. The samples were then prepared and analyzed for Au by conventional fire assay-atomic absorption spectrometry (FA-AAS) [20], as FA-AAS is generally accepted as dependable analytical method for gold [21].

Generally, the basic procedure for fire assay involves the mixing of a powdered sample (10 g - $50 \mathrm{~g}$ ) with sodium carbonate (ash), borax (sodium borate), litharge, flour and silica. A foil of $\mathrm{Pb}$ or Ag is usually added as a collector. The mixture is then fired at a temperature ranging from $1000^{\circ} \mathrm{C}-1200^{\circ} \mathrm{C}$. The obtained lead button is then removed by cupellation at $950^{\circ} \mathrm{C}$. The resultant gold prill is digested with aqua regia mixture and the solution analysed by atomic absorption spectrometer using gold standards. The other trace elements, namely As, Ag, Pb, $\mathrm{Fe}$, and $\mathrm{Cu}$ were analyzed using routine Inductively Coupled Plasma Mass Spectrometry (ICP-MS).

On the analyzed historical data, descriptive statistics including mean, minimum, maximum and standard deviation were calculated for the respective elements. These indicated a significant departure of the datasets from normality and as such, the need to normalize it via logarithmic transformation. The very nature of geochemical data makes them rather spatially dependent and as such inherently non-normal. Additionally, the prime assumption underlying the application of the multivariate methods of FA and HCA is for the data to follow normal distribution. To identify the relationship among trace elements and gold and their possible sources, multivariate statistical analyses, such as factor analysis and hierarchical cluster analysis, were performed using statistical software package SPSS [22].

The results of HCA are presented in the form of a dendrogram where procedures in the hierarchical clustering solution and values of the distances between clusters (squared Euclidean distance) are represented [23]. The process starts by calculating the similarity/dissimilarity between the N objects. Then two objects which when clustered together minimize a given agglomeration criterion, are clustered together thus creating a class comprising these two objects. Then the dissimilarity between this class and the N-2 other objects is calculated using the agglomeration criterion. The two objects or classes of objects whose clustering together minimizes the agglomeration criterion are then clustered together. This process continues until all the objects have been clustered. These successive clustering operations produce a binary clustering tree (dendrogram), whose root is the class that contains all the observations. This dendrogram represents a hierarchy of partitions. It is then possible to choose a partition by truncating the tree at a given level, the level depending upon either user-defined constraints (the user knows how many classes are to be obtained) or more objective criteria. In this study, a phenon line was drawn across the dendrogram so developed for the determination of the most optimal clusters to define the dataset. To calculate the dissimilarity between the various variables, different methods are possible but the Wards method was considered for this work. Earlier, squared Euclidean distances were used to determine measures of similarities/dissimilarities amongst the parameters for the distinguishing of initial clusters. This method aggregates two groups so that within-group inertia increases as little as possible to keep the clusters homogeneous. This criterion, proposed by Ward [24], can only be used in cases with quadratic distances, i.e. cases of Euclidian distance and Chi-square distance.

Factor analysis method dates from the start of the 20th 
century [25] and has undergone a number of developments, several calculation methods having been put forward. This method was initially used by psychometriccians, but its field of application has little by little spread into many other areas, for example, geology. Factor analysis, involves the extraction of principal components from the initial dataset. Each principal component is expected to represent a process or set of processes which influence the spatial variation of the values of the parameters. The Kaiser [26] criterion was used to determine the number of components to extract. This method suggests that only those factors with associated eigenvalues which are strictly greater than or equal to 1 should be kept. The scree plot can also be used to determine the number of factors which represent unique sources of variation in the dataset. In that respect, the number of factors to be kept corresponds to the first turning point found on the curve of the scree plot [27]. "Principal components" was used as the extraction method. The method of principal components can be seen as a projection method which projects observations from a p-dimensional space with $\mathrm{p}$ variables to a $\mathrm{k}$-dimensional space (where $\mathrm{k}<\mathrm{p}$ ) so as to conserve the maximum amount of information (information is measured here through the total variance of the scatter plots) from the initial dimensions. If the information associated with the first 2 or 3 axes represents a sufficient percentage of the total variability of the scatter plot, the observations will be able to be represented on a 2 - 3-dimensional chart, thus making interpretation much easier. This method of extraction enabled the calculation of matrices to project the variables in a new space using a new matrix which shows the degree of similarity between the variables. The covariance matrix was used as the index of similarity.

\section{Results and Discussion}

\subsection{Summary Statistics}

Summary statistics of multi-element analysis of $\mathrm{Au}, \mathrm{As}$, $\mathrm{Ag}, \mathrm{Pb}, \mathrm{Cu}, \mathrm{Fe}$ and $\mathrm{Mn}$ analytical results are displayed in Table 1. Table 2 also displays statistics for the same set of data after a logarithmic transformation was applied to the dataset. A brief comparison of the two tables is made using Fe as an example.

There is a very large disparity between the median and maximum value in Figure 2. Iron has a median value of $31,100 \mathrm{mg} / \mathrm{kg}$ and a maximum of $155,900 \mathrm{mg} / \mathrm{kg}$ with an even lower mean of $43,186 \mathrm{mg} / \mathrm{kg}$. The result is a longer whisker above the mean and a shorter one below it. This implies that, most of the Fe values greatly depart from the mean which is also an indication of the extreme variability of geochemical data. This trend in any dataset makes it rather difficult to be used in any multivariate analysis since the data is obviously non-normal. A log
Table 1. Summary statistics of multi-element analysis results.

\begin{tabular}{lcllll}
\hline \multicolumn{7}{c}{ Variable } & Observations Minimum Maximum & Mean & SD \\
\hline Au_mg/kg & 253 & 0.001 & 0.174 & 0.006 & 0.013 \\
Ag_mg/kg & 253 & 2.000 & 60.000 & 7.012 & 7.443 \\
As_mg/kg & 253 & 5.000 & 203.000 & 27.621 & 35.050 \\
$\mathrm{Cu}$ _mg/kg & 253 & 3.000 & 139.000 & 34.557 & 27.777 \\
$\mathrm{Fe} \_\mathrm{mg} / \mathrm{kg}$ & 253 & 7100.000 & 155900.000 & 43186.957 & 33063.880 \\
$\mathrm{~Pb} \_\mathrm{mg} / \mathrm{kg}$ & 253 & 0.001 & 0.043 & 0.005 & 0.006 \\
$\mathrm{Mn}$ _mg $/ \mathrm{kg}$ & 253 & 40.000 & 4210.000 & 712.945 & 768.442 \\
\hline
\end{tabular}

Table 2. Summary statistics of log transformed data.

\begin{tabular}{lccccc}
\hline Variable & Observations & Minimum & Maximum & Mean & SD \\
\hline log_Au & 253 & -3.000 & -0.759 & -2.555 & 0.500 \\
log_Ag & 253 & 0.301 & 1.778 & 0.703 & 0.323 \\
log_AS & 253 & 0.699 & 2.307 & 1.127 & 0.512 \\
log_Cu & 253 & 0.477 & 2.143 & 1.416 & 0.332 \\
Log_Fe & 253 & 3.851 & 5.193 & 4.532 & 0.293 \\
Log_Pb & 253 & -3.000 & -1.367 & -2.500 & 0.436 \\
Log_Mn & 253 & 1.602 & 3.624 & 2.660 & 0.407 \\
\hline
\end{tabular}

Box plot (Fe_mg/kg)

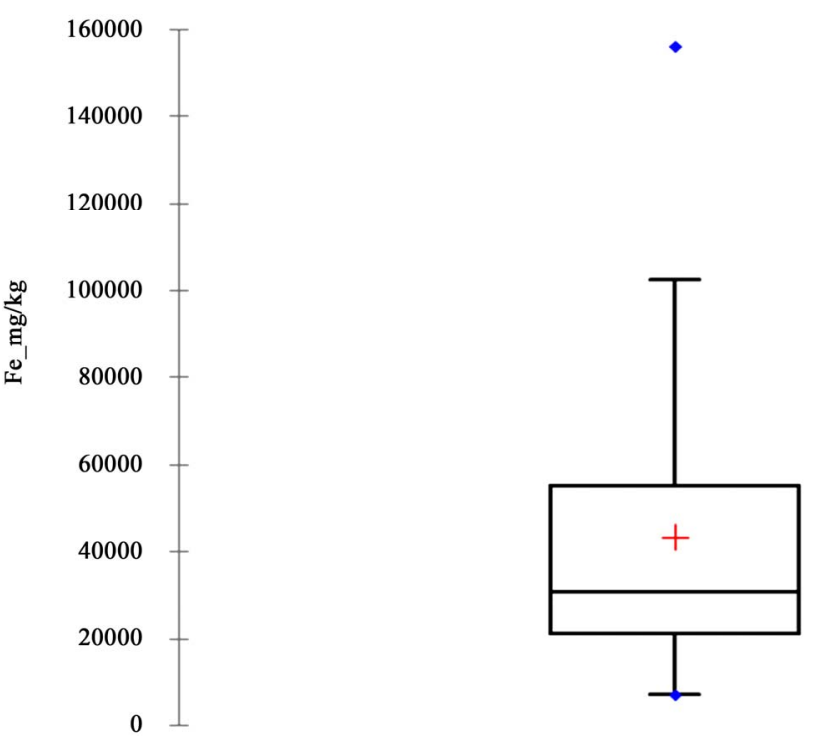

Figure 2. Box plot of Fe using Table 1 (before transformation).

transformation as shown in Figure 3 gives a more refined dataset with both the maximum and minimum values evenly distributed about the mean value. This trend indicates a more uniform dataset with a smaller and more stable variance which aids greatly in data analysis.

\subsection{Cluster Analysis}

An R-mode clustering schedule produced the dendrogram in Figure 4. The resultant clustering has $\mathrm{Au}, \mathrm{Pb}$ and $\mathrm{As}$ 


\section{Box plot (log_Fe)}

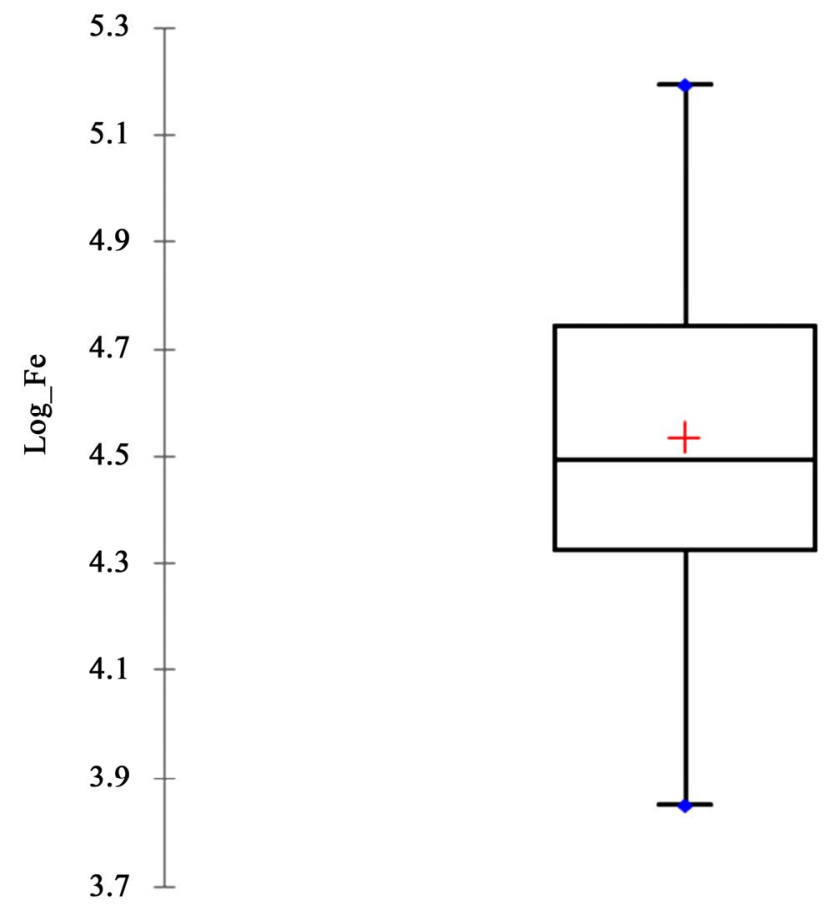

Figure 3. Box plot of Fe using Table 2 (after transformation).

Dendrogram using Ward Method

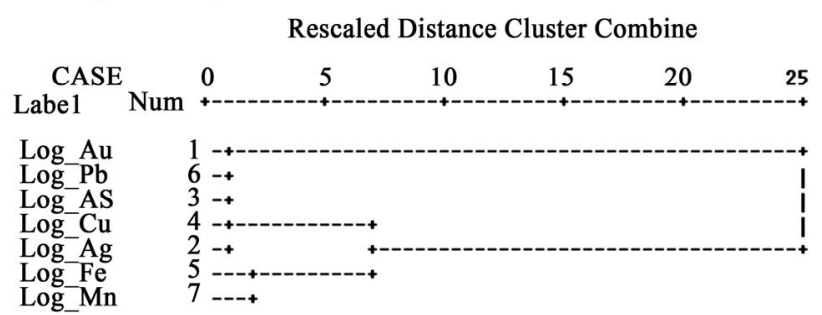

Figure 4. Dendrogram displaying clusters of multi-elemental analysis results.

in the first cluster. As can be deduced from their dissimilarity index, this group happens to be the most homogeneous pair arising from the fact that they contribute the least concentrations within the soil samples analyzed. They have average concentrations of 0.006 and $0.005 \mathrm{mg} / \mathrm{kg}$ respectively. This concentration of $\mathrm{Au}$ is however not completely dissatisfying since native gold appears in rather small concentrations. The second cluster has Ag, Fe, $\mathrm{Mn}$, and $\mathrm{Cu}$ as its members with their respective average concentrations being 7.012, 27.621 and $34.557 \mathrm{mg} / \mathrm{kg}$. This cluster has As and $\mathrm{Cu}$ being the most homogeneous pair. Iron and manganese are the most abundant amongst the analyzed samples. Gold is known to be fixed after dispersion in secondary mineral hosts such as Fe-Mn and Al-Fe hydroxides. Besides, volcanicalstic rocks are abundant in the study area and are known to contain high amounts of ferromagnesian minerals. Additionally, gold occurrence in the study area is also of the arsenopyrite/porphyry copper nature. Evidence of this is the porphyry copper deposits discovered in neighboring Burkina Faso which is of the same geological formation.

However, the fairly distributed concentrations of silver, lead, and arsenic are not completely dissatisfying since aiding in gold prospecting is the prime objective. Although performing HCA on variables rather than on cases is preferred in most research studies [28,29], HCA was developed, in the present study, on soil samples, in order to identify similarities in Au contents and that of the trace elements. This approach was selected instead of trying to discriminate between the different sources of metals, which would be accounted for by FA. Thus, the aim in performing HCA was to identify the samples which represented different areas where Au content followed a similar pattern. This different approach was preferred since, in that sense, the results provided by Q-mode HCA and R-mode FA, in this work, is complementary, although they are not quite different methods. FA helped to group the elements according to their underlying geological factors. Once this information is known, HCA allowed clustering the areas with high $\mathrm{Au}$ content and its associated trace element concentration.

Three main clusters can be distinguished in the dendrogram shown in Figure 5. This method is distinct from all other methods because it uses an analysis of variance approach to evaluate the distances between clusters. Cluster one includes about 107 samples which has associated with it concentrations of, As, Ag, Mn \& Fe with rather low concentrations of $\mathrm{Pb}, \mathrm{Cu}$ and particularly $\mathrm{Au}$. The second cluster, comprising of the least number of samples, clusters samples with the highest $\mathrm{Au}$ concentration with a rather predictable high As concentration. This is so because, disseminated sulphide type of ore has been documented in the area and according to Leube et al. [6], sericite- and pyrite/arsenopyrite-rich selvages frequently carry gold in the structure controlled deposit types of the Wa-Lawra belt. The third cluster which has the largest number of samples also appears to be highly concentrated in $\mathrm{Cu}, \mathrm{Pb}, \mathrm{Fe}$ and $\mathrm{Mn}$. Its $\mathrm{Au}$ content is slightly higher in relation to that of the first cluster but however, considerably lower to the second cluster. The respective $\mathrm{Au}$ and trace element concentration of the various samples within each of the three clusters was arrived at by computing the arithmetic mean of each elemental concentration. Due to the extent of the data, and also because of the unequal number of samples in each cluster, an average of 45 samples each was considered. Au had an average concentration of $0.091 \mathrm{mg} / \mathrm{Kg}$ in cluster two representing the highest. Clusters one and three had concentrations of $0.0010 \mathrm{mg} / \mathrm{kg}$ and $0.0014 \mathrm{mg} / \mathrm{kg}$ respectively. Besides, it can be generally observed that, clusters with 


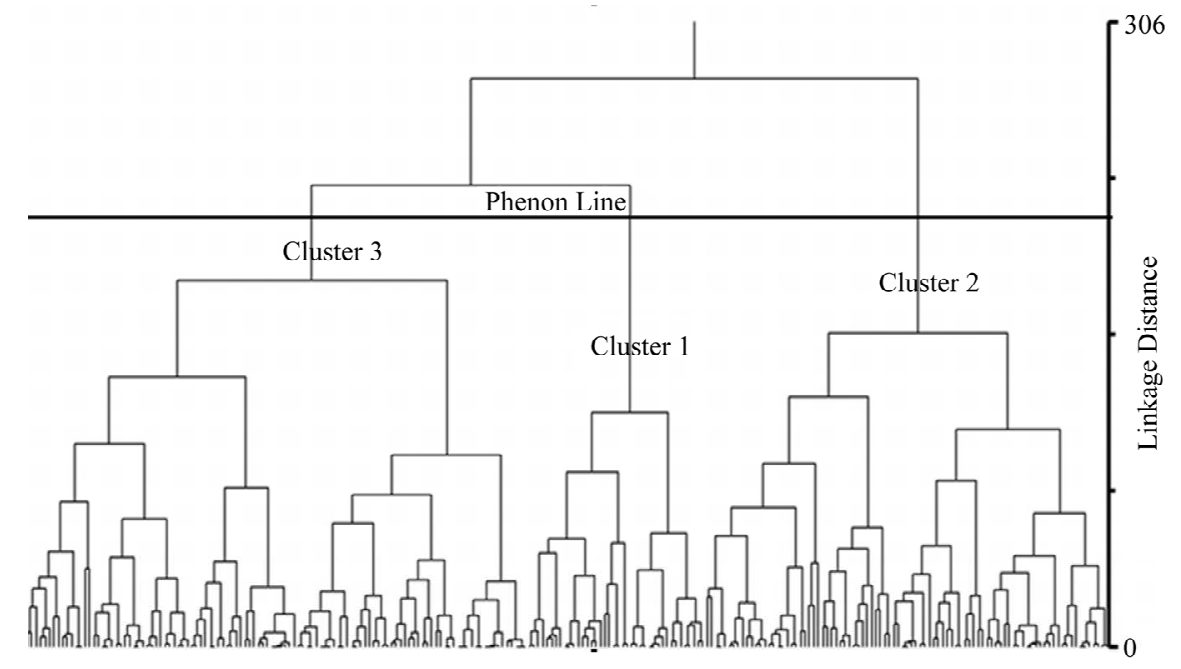

Figure 5. Dendrogram from Q-mode HCA.

higher concentrations of Au have an associated fair concentration of As, $\mathrm{Cu}$ and Ag. The above clustering criterion can alternately be described as "dissimilarity clustering" with the phenon line chosen at dissimilarity index of 20. Reducing the height of the phenon line would result in having more clusters which are closely related.

\subsection{Factor Analysis}

"Principal components" was the method of extraction used. The analysis indicated three factors in the data accounting for $79.093 \%$ of the total variability. Table 3 indicates the variance explained for each of the factors extracted. The factor model showing the loadings of the various variables under each factor is presented in Table 4.

It is obvious from Table 3 that the first factor which accounts for $34.73 \%$ of total variance is dominated by copper, iron, lead, and manganese associated with some contribution of silver, while the second is the As factor with some positive loading with lead, which explained $23.46 \%$, and the third though having Au as the dominant factor, also has some positive associations with $\mathrm{Fe}, \mathrm{Pb}$ and Mn which explained $20.90 \%$ of the total variance. A

Table 3. Total variance explained.

\begin{tabular}{cccccccc}
\hline \multicolumn{2}{c}{ Component } & Total & $\begin{array}{c}\% \text { of } \\
\text { Variance }\end{array}$ & $\begin{array}{c}\text { Cumulative } \\
\%\end{array}$ & Total & $\begin{array}{c}\% \text { of } \\
\text { Variance }\end{array}$ & $\begin{array}{c}\text { Cumulative } \\
\%\end{array}$ \\
\hline 1 & 0.406 & 34.729 & 34.729 & 0.406 & 34.729 & 34.729 \\
2 & 0.274 & 23.462 & 58.19 & 0.274 & 23.462 & 58.19 \\
3 & 0.244 & 20.903 & 79.093 & 0.244 & 20.903 & 79.093 \\
4 & 0.109 & 9.311 & 88.404 & & & \\
5 & 0.08 & 6.835 & 95.239 & & & \\
6 & 0.042 & 3.618 & 98.857 & & & \\
7 & 0.013 & 1.143 & 100 & & & \\
\hline
\end{tabular}

Table 4. Component matrix.

\begin{tabular}{cccc}
\hline variable & \multicolumn{3}{c}{ Component } \\
\hline Log_Au & -0.405 & 0.065 & 0.901 \\
Log_Ag & 0.447 & 0.099 & -0.237 \\
Log_As & -0.091 & 0.979 & -0.086 \\
Log_Cu & 0.837 & -0.177 & 0.107 \\
Log_Fe & 0.862 & 0.031 & 0.215 \\
Log_Pb & 0.722 & 0.295 & 0.213 \\
Log_Mn & 0.785 & -0.008 & 0.346 \\
\hline
\end{tabular}

plot of the factor loadings of factors 1 and 2 on the various elements is shown in Figure 6. The geology of the area particularly the rock formations present in the study area can be associated with factor 1. It is known that, the area is underlain by volcanic rocks which are particularly rich in ferromagnesium minerals. This can also be attributed to the presence of chemical sediments and magnesium-rich rocks known as gondites. These chemical sediments inter flow the rock formations carrying in its path other constituents contributing to the loadings observed with factor one. Also, copper transport is known to be via volcanic activity and thus, the vast nature of volcaniclastic rock formations present in the area would have an associated copper content. Additionally, copper is found in association with other metals such as $\mathrm{Pb}$ which is also generally associated with Ag.

The association of copper, iron, lead and manganese with factor 1 is shown in Figure 6. The association of As with sulphide in the area is also made evident in factor 2 . Factor 3 being the $\mathrm{Au}$ factor with some $\mathrm{Cu}, \mathrm{Fe}, \mathrm{Pb}$, and $\mathrm{Mn}$ association can be attributed to the hydrothermal processes responsible for their emplacement. This process is 
Factor loadings (axes F1 and F2: 58.19\%)

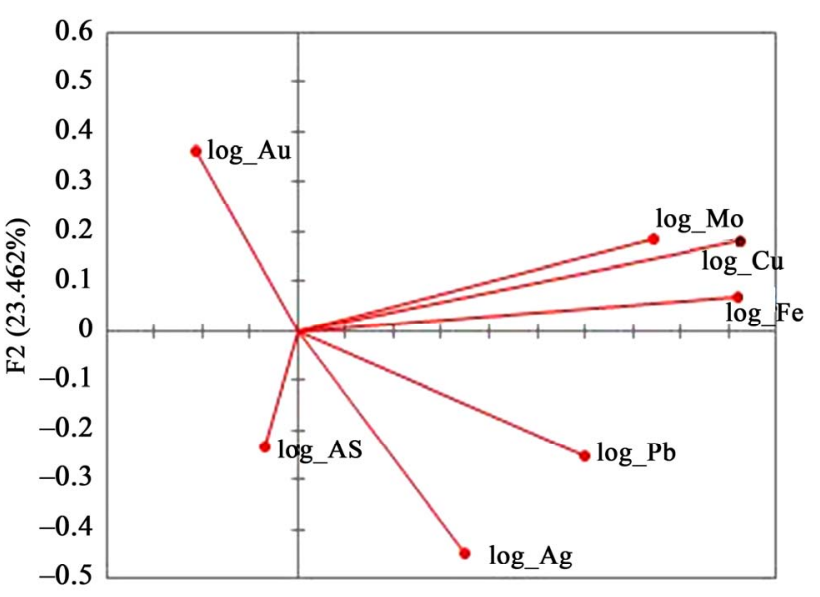

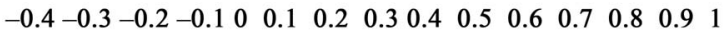

F1 (34.729\%)

Figure 6. Plot of factor loadings of factors 1 and 2.

chiefly responsible for Au mineralization in the area. Hydrothermal deposits are generally associated with some $\mathrm{Pb}, \mathrm{Cu}$ and $\mathrm{Ag}$ enrichment particularly the disseminated sulphide type which occurs in the area. The association between gold and these elements [30] stems from the fact that, the gold in the Lawra belt is concentrated by volcanic related processes, principally chemical precipitation in exhalative sediments. The gold and associated minerals were remobilized from these chemical sediments by metamorphogenic processes with the auriferous fluid transported and deposited in structurally favorable sites. Futhermore, during weathering trace elements such as $\mathrm{Cu}$ and $\mathrm{Au}$ can be preferentially absorbed and trapped in $\mathrm{Al}-\mathrm{Fe}$ and $\mathrm{Fe}-\mathrm{Mn}$ hydroxides. Gold co-exists with $\mathrm{As}, \mathrm{Cu}$, $\mathrm{Pb}$ and $\mathrm{Fe}$ released from arsenopyrite, chalcopyrite, galena and sphalerite among others, in the oxidized environment during weathering and adsorbed on to the surfaces of Fe-hydroxides such as goethite and hematite or trapped in kaolinite in the regolith. Most tropical soils are rich in Fe-hydroxides which are able to fix weighted elements such as gold and have affinity for As [2].

\section{Implications for Gold Exploration in the Wa-Lawra Belt}

In the Birimian of southwestern Ghana where major gold deposits have been found, arsenopyrite (FeAsS), chalcopyrite $\left(\mathrm{CuFeS}_{2}\right)$ and pyrite $\left(\mathrm{FeS}_{2}\right)$ are noted to be the major host minerals of gold $[4,5,31]$. These sulphide minerals may host trace elements such as arsenic (As), $\mathrm{Cu}$, $\mathrm{Zn}, \mathrm{Ni}, \mathrm{Pb}$ and $\mathrm{Au}$ etc. [5] as pathfinder elements which have led to exploration success in the Birimian of southwestern Ghana. However, from the present study $\mathrm{Fe}, \mathrm{Pb}$, $\mathrm{Mn}, \mathrm{Ag}$, As and $\mathrm{Cu}$ appear to be associated with $\mathrm{Au}$ and therefore suitable as pathfinder elements. Thus despite similarities in geology and structural setting of the WaLawra belt with the belts in southwestern Ghana, differences in pathfinder elements appear to exist. This is probably due to the nature of the regolith resulting from weathering and landscape processes. The association of $\mathrm{Fe}$ and $\mathrm{Mn}$ with $\mathrm{Au}$ in this study is unique and appears to differ from what pertains in southern Ghana. The WaLawra belt is largely lateriric and the regolith is dominated by Fe-oxides/oxyhydroxides. It is possible that $\mathrm{Au}$ mineralization is strongly associated with ferruginization; Fe-Mn oxides being secondary phases are capable of gold encrustation and therefore possible hosts to Au mineralization. They should therefore be considered as targets for $\mathrm{Au}$ exploration in the area.

\section{Conclusion}

The application of both factor analysis and hierarchical cluster analysis to historical multi-element soil geochemical data from the Koda Hill-Bulenga area in Wa-Lawra belt of Ghana showed that, gold was associated with copper, iron, lead and manganese. Factor analysis also showed that gold and these element associations occurred in tandem, which can be explained via the same underlying geological factors. The results of factor analysis made it possible for the initial seven variables and 253 samples to be reduced to three factors representing $79 \%$ of the total variance explained. From hierarchical clustering, gold was also observed to be clustering with lead, copper, arsenic and silver. There was further indication that, gold concentrations were lower than that of its associations $(\mathrm{Fe}, \mathrm{Pb}$, $\mathrm{Mn}, \mathrm{Ag}$, As and $\mathrm{Cu}$ ). It can be inferred from these results that, the occurrence of gold and its associated elements was due to both primary dispersion from underlying rocks and secondary processes such as lateritization. Iron and $\mathrm{Mn}$ alongside $\mathrm{Pb}, \mathrm{Ag}$, As and $\mathrm{Cu}$ can be used as pathfinders for gold in the area with ferruginous zones as targets.

\section{REFERENCES}

[1] E. Arhin and P. M. Nude, "Significance of Regolith Mapping and Its Implication for Gold Exploration in Northern Ghana: A Case Study at Tinga and Kunche,” Geochemistry: Exploration, Environment and Analysis, Vol. 9, 2009, pp. 63-69. doi:10.1144/1467-7873/08-189

[2] G. K. McQueen and D. C. Munro, "Weathering-Controlled Fractionation of Ore and Pathfinder Elements at Cobar, NSW,” In: I. C. Roach, Ed., Advances in Regolith, 2003, pp. 296-300.

[3] R. R. Anand, J. E. Wildman, Z. S. Varga and C. Phang, "Regolith Evolution and Geochemical Dispersion in Transported and Residual Regolith-Bronzewing Gold Deposit," Geochemistry: Exploration, Environment, Analysis, Vol. 1, No. 12, 2001, pp. 256-276.

[4] G. O. Kesse, “The Mineral and Rock Resources of 
Ghana,” A. A. Balkema Press, Rotterdam, 1985, p. 610.

[5] R. J. Griffis and F. L. Agezo, "Mineral Occurrences and Exploration Potential of Northern Ghana,” Minerals Commission Report, Accra, 2000.

[6] A. Leube, W. Hirdes, R. Mauer and G. O. Kesse, "The Early Proterozoic Birimian Supergroup of Ghana and Some Aspects of Its Associated Gold Mineralization,” Precambrian Research, Vol. 46, No. 1-2, 1990, pp. 139-165. doi:10.1016/0301-9268(90)90070-7

[7] P. N. Taylor, S. Moorbath, A. Leube and W. Hirdes, "Early Proterozoic Crustal Evolution in the Birimian of Ghana: Constraints from Geochronology and Isotope Geology,” Precambrian Research, Vol. 56, No. 1-2, 1992, pp. 77-111. doi:10.1016/0301-9268(92)90086-4

[8] W. Hirdes, D. W. Davis and B. N. Eisenlohr, "Reassessment of Proterozoic Granitoids Ages in Ghana on the Basis of U/Pb Zircon and Monazite Dating," Precambrian Research, Vol. 56, No. 1-2, 1992, pp. 89-96. doi:10.1016/0301-9268(92)90085-3

[9] P. M. Nude and E. Arhin, "Overbank Sediments as Appropriate Geochemical Sample Media in Regional Stream Sediment Surveys for Gold Exploration in Savannah Regions of Northern Ghana,” Journal of Geochemical Exploration, Vol. 103, No. 1, 2009, pp. 50-56. doi:10.1016/j.gexplo.2009.06.005

[10] K. B. Dickson and G. Benneh, “A New Geography of Ghana,” Longman Group Ltd., London, 1988.

[11] N. R. Junner, "Gold in the Gold Coast," Gold Coast Geological Survey, Vol. 4, 1935, p. 67.

[12] P. Carter, "Wa Reconnaissance Licence, Terminal Report Prepared for the Minerals Commission Ghana," AshantiAGEM Alliance Internal Report, 1997.

[13] AGEM, "Terminal Report on Lawra-Wa Reconnaissance License,” Unpublished Internal Report, 1996.

[14] F. Melcher and E. Stumpfl, "Chemical Facies and Gold Mineralisation in Northern Ghana,” Zeitschrift Feur Angewandte Geologie, Vol. 39, No. 859A, 1993, pp. 43-46.

[15] G. Matheron, “The Theory of Regionalized Variables and Its Applications. Les Cahiers du Centre de Morphologie Mathématique,” Fascicule V. Ecole de Mine de Paris, 1970, p. 211.

[16] A. G. Journel and C. J. Huijbregts, "Mining Geostatistics,” Academic Press, New York, 1978.

[17] J. C. Davis, "Statistics and Data Analysis in Geology," 2nd Edition, John Willey and Sons, New York, 1987.

[18] C. Reimann, P. Filzmoser and R. G. Garrett, "Back Ground and Threshold: Critical Comparison of Methods of Determination," Science of the Total Environment, Vol. 346, No. 1-3, 2005, pp. 1-16. doi:10.1016/j.scitotenv.2004.11.023

[19] R. J. Howarth and G. J. S. Govett, "Handbook of Exploration Geochemistry, Vol. 2: Statistics and Data Analysis in Geochemical Prospecting,” Elsevier, Amsterdam, 1983.

[20] T. A. Delaney and W. K. Fletcher, "Efficiency of Cyani Dation in Gold Exploration Using Soils," Journal of Geochemical Exploration, Vol. 66, No. 1-2, 1999, pp. 229-239. doi:10.1016/S0375-6742(99)00007-2

[21] R. Juvonen and E. Kontas, "Comparison of Three Analytical Methods in the Determination of Gold in Six Finnish Gold Ore, Including a Study on Sample Preparation and Sampling,” Journal of Geochemical Exploration, Vol. 65, No. 3, 1999, pp. 219-229. doi:10.1016/S0375-6742(99)00030-8

[22] SPSS, “SPSS Statistics 17 Brief Guide,” SPSS Incorporated, Chicago, 2008.

[23] Y. P. Lin, T. P. Teng and T. K. Chang, "Multivariate Analysis of Soil Heavy Metal Pollution and Landscape Pattern in Changhua County in Taiwan," Landscape and Urban Planning, Vol. 62, No. 1, 2002, pp. 19-35. doi:10.1016/S0169-2046(02)00094-4

[24] J. H. Ward, "Hierarchical Grouping to Optimize an Objective Function," Journal of the American Statistical Association, Vol. 58, No. 301, 1963, pp. 238-244. doi:10.2307/2282967

[25] C. Spearman, "General Intelligence Objectively Determined and Measured," American Journal of Psychology, Vol. 15, No. 2, 1904, pp. 201-293. doi:10.2307/1412107

[26] H. F. Kaiser, "The Application of Electronic Computers to Factor Analysis,” Educational and Psychological Measurement, Vol. 20, No. 1, 1960, pp. 141-151. doi:10.1177/001316446002000116

[27] R. B. Cattell, “The Scree Test for the Number of Factors," Multivariate Behavioral Research, Vol. 1, No. 2, 1966, pp. 245-276. doi:10.1207/s15327906mbr0102_10

[28] A. Facchinelli, E. Sacchi and L. Mallen, "Multivariate Statistical and GIS-Based Approach to Identify Heavy Metal Sources in Soils,” Environmental Pollution, Vol. 114, No. 3, 2001, pp. 313-324. doi:10.1016/S0269-7491(00)00243-8

[29] M. G. Yalcin, I. Narin and M. Soylak, "Multivariate Analysis of Heavy Metal Contents of Sediments from Gumusler Creek, Nigde, Turkey,” Environmental Geology, Vol. 54, No. 6, 2008, pp. 1155-1163. doi:10.1007/s00254-007-0884-6

[30] F. Karikari, "GIS-Based Predictive Mapping of Lode Gold Potential in the Lawra Belt, Northwest Ghana,” International Institute for Geo-Information Science and Earth Observation, Enschede, 2002.

[31] K. Dzigbodi-Adjimah, "Geology and Geochemical Patterns of the Birimian Gold Deposits, Ghana, West Africa,” Journal of Geochemical Exploration, Vol. 47, No. 1-3, 1993, pp. 305-320. doi:10.1016/0375-6742(93)90073-U 